\title{
Golongan Tua Menggagas Pergerakan Nasional: Pemikiran R.M.T Koesoemo Oetoyo di Bidang PolitikTahun 1908-1942
}

\author{
Reni Dikawati dan Ajat Sudrajat*
}

\begin{abstract}
Abstrak
Penelitian ini bertujuan menganalisis pemikiran dan peranan R.M.T Koesoemo Oetoyo sebagai golongan tua yang mengkonsep dan berperan dalam pergerakan nasional Indonesia di bidang politik tahun 1908-1942. Penelitian ini menggunakan metode penelitian sejarah. Adapun tahapan yang dirumuskan menurut langkah-langkah penelitian sejarah Kuntowijoyo, yaitu pemilihan topik, heuristik, verivikasi, intrepretasi, dan historiografi. Sumber data berupa sumber primer dan sekunder yaitu arsip, memo, notulen, dokumen, foto, koran, wawancara, dan buku.

Hasil penelitian menunjukkan pembaharuan pengetahuan sejarah, yaitu pelurusan bahwa tidak semua golongan tua bersifat moderat. Melihat semangat zaman pada masa itu, Koesoemo Oetoyo merupakan tokoh yang revolusioner dibandingkan pangreh praja pada masanya, dengan mendukung dan mengkonsep pergerakan nasional yang sesuai untuk arah pergerakan bangsa. Pergerakan nasional dalam konsep pemikiran Oetoyo merupakan usaha perbaikan dalam segala aspek kehidupan politik, sosial, dan ekonomi, ketiganya merupakan satu kesatuan yang tidak bisa dipisahkan. Politik dipandang sebagai alat mencapai tujuan, sehingga perlu pendekatan yang sesuai dengan semangat zaman pada masa itu, yaitu diplomasi. Konsepsi pemikiran Oetoyo mampu mengakomodasi keanekaragaman organisasi pergerakan menjadi satu kesatuan partai sebagai wakil rakyat, yaitu Parindra. Peran Koesoemo Oetoyo dalam politik yaitu mendorong lahirnya organisasi pertama pangreh praja (Sedio Muljo), mendirikan Dewan Desa dan Dewan Kabupaten, menjadi Ketua Boedi Oetomo, anggota Volksraad, Fraksi Nasional, menuntut otonomi dan Indonesia berparlemen.
\end{abstract}

Kata Kunci: Pemikiran, Koesoemoe Oetoyo, pergerakan nasional, 1908-1942

\section{Pendahuluan}

Penjajahan Belanda di Indonesia mengakibatkan adanya kesengsaraan di berbagai bidang kehidupan yang terus menimbulkan tekanan dan inferiortas rakyat. Sistem pemerintahan Hindia Belanda dengan tegas menempatkan masyarakat pribumi sebagai second person di bawah orang-orang kulit putih dan Timur Asing (Sartono K, 1972: 55). Konsekuensinya, dalam segala akses fasilitas umum rakyat pribumi dibatasi hakhaknya. Pribumi hanya menjadi objek kebijakan, bukan sebagai subjek dari kebijakan tersebut. Bahkan untuk meredam pergolakan yang disebabkan oleh keterpurukan akibat dibukanya modal swasta, pemerintah memberlakukan politik balas jasa, atau yang dikenal dengan kebijakan poltik etis.

Politik etis bila dilihat dari konteks pemerintah Hindia Belanda pada masa itu sebenarnya hanya dijadikan sebagai pengecoh rakyat, agar menilai pemerintah dengan kesungguhan ingin mengarahkan masyarakat pada perubahan. Padahal taktik 
itu merupakan wujud baru penjajahan, dan tetap pada koridor untuk kepentingan Belanda. Pemerintah tidak sepenuhnya bertujuan memberikan kesempatan pribumi mengenyam pendidikan, sebagaimana konsep pendidikan sekarang ini, untuk mencerdaskan dan memberikan bekal memperbaiki kehidupan. Melainkan sebagai pemenuhan atas kebutuhan tenaga kerja murah pemerintah.

Kemajuan yang diidentikan dengan pembangunan kearah modernitas pada masa politik etis, telah menyadarkan para elit terdidik untuk merefleksikan dalam realitas yang ada di masyarakat. Kemajuan yang dialami oleh masyarakat Indonesia bukan untuk mensejahterakan pribumi, justru semakin menciptakan adanya kesenjangan (Suhartono, 2010; 3).

Pemerintah Hindia Belanda dengan jelas menggunakan standartnya untuk mengukur struktur pemerintah, sedangkan pribumi hanya menjadi orang asing di negaranya sendiri. Konsepsi ini menggerakkan elit terpelajar mengupayakan kesadaran kepada masyarakat pentingnya bersatu dengan mengakomodasi paham nasionalisme yang telah berkembang di Barat ke arah pergerakan nasional.

Pergerakan nasional merupakan tonggak awal adanya suatu konsepsi masyarakat Hindia Belanda untuk melakukan perlawanan terhadap penjajahan Belanda melalui internalisasi nasionalisme. Pergerakan nasional mengarah pada perubahanorientasi dan lingkup yang tidak hanya bersifat kedaerahan, tanpa arah, dan tujuan, melainkan telah mendasar pada doktrin kemerdekaan serta kedaulatan rakyat.

Pola pergerakan nasional juga tidak terlepas dari ide, pikiran, motif, kesadaran yang dihubungkan dengan lingkungan yang konkrit dari situasi sosio historis termasuk tokoh penggeraknya. Tokoh penggerak inilah yang mengagasdan mempengaruhi sebagian besar pengambilan keputusan maupun cara yang digunakan untuk mencapai suatu tujuan (Teguh W, 2011: 9).

Gabungan dari pemikiran dan cara pergerakan memberikan ciri yang khas pada pola pergerakan suatu organisasi. Organisasi pergerakan dianggap sebagai tindakan kelompok untuk menghadapi kondisi hidup dengan jalan mengadakan reaksi yang sesuai dengan posisi kelompok tersebut. Konsekuensinya, untuk memahami latar belakang, motif dan tujuansuatu organisasi pergerakan harus dikembalikan pada konsep pemikiran pemimpinnya.

Perbedaan cara pandang dalam menseminasikan paham nasionalisme, dan pergerakan nasional menyebabkan lahirnya organisasi sebagai institusionalisasi tindakan sosial yang ditujukan kearah politik, sosial, ekonomi sesuai sudut pandang pengonsep dan tidak jarang menimbulkan pertentangan dan gesekan 
antar organisasi pergerakan yang ada. Perbedaan cara pandang tokoh pergerakan dalam mengarahkan organisasi pergerakan sangat jarang ditonjolkan (Pradipto N, 2011; 87). Narasi yang berkembang menunjukkan kesenjangan antara golongan tua (priyayi) dengan golongan muda. Kesenjangan tersebut telah membuat seolah pergerakan nasional terputus oleh sekat yang dihidupkan melalui narasi moderat dan revolusioner.

$\begin{array}{ccc}\text { Makna } & \text { revolusioner } & \text { sendiri } \\ \text { mengarah } & \text { pada bias, } & \text { dengan }\end{array}$
mengartikannya sebagai hal luar biasa melalui angkat senjata ataupun menyerang, tentu harus dilihat dari konteks semangat zaman. Golongan tua yang selama ini dinarasikan sebagai kelompok pasif terhadap pergerakan tidak sepenuhnya tepat. Koesoemoe Oetoyo merupakan salah satu tokoh dari golongan priyayi yang mengonsep pergerakan nasional Indonesia, bahkan implementasi konsepnya mampu mengatasi pergolakan intern dalam tubuh organisasi pergerakan di Indonesia pada masa itu.

Oetoyo memenuhi kriteria sebagai tokoh dan ditokohkan dalam Pergerakan Nasional Indonesia. Kriteria sebagai tokoh dapat diukur melalui terpenuhinya tiga persyaratan. Pertama, berhasil di bidangnya, kedua, memiliki karya monumental, dan ketiga mempunyai pengaruh di masyarakat. Oetoyo dapat dikatakan ditokohkan karena peranannya dalam pergerakan nasional diakui oleh masyarakat, dibuktikan dengan dibangunnya Jalan Kusuma Utoyo di Jepara, Jawa Tengah untuk mengenang jasanya. Pemikiran dan peranan Koesoemo Oetoyo menjadi sangat penting untuk melihat relevansi konsepnya hingga sekarang.

Peranannya dalam pergerakan nasional melalui Dewan Desa, dewan Kabupaten, Sedio Muljio, Budi Utama, Volksraad, Fraksi Nasional perlu pengkajian lebih lanjut. Penelitian juga dapat dijadikan sebagai pembelajaran yang mengajarkan bagaimana sebenarnya mengarahkan masyarakat pada tataran kesejahteraan melalui kebijakan-kebijakan politik.

\section{Tinjauan Pustaka}

\section{A. Pergerakan Nasional}

Lahir dan perkembangan pergerakan nasional Indonesia di dorong oleh adanya faktor intern dan ekstern. Secara Intern, pergerakan nasional adalah hasil dari perkembangan faktor ekonomi, sosial, politik, kultural, dan religius, serta interelasi antara faktor-faktor tersebut. Secara ekstern pergerakan nasional Indonesia tidak dapat dipisahkan dari adanya komunikasi media masa yang memberitakan perlawanan menentang penjajahan di berbagai belahan dunia. Kedua faktor tersebut memiliki dampak yang cukup besar terhadap semangat perlawanan menentang penjajahan. Peristiwa perlawanan di berbagai belahan 
dunia yang ikut menjadi pemicu pergerakan di Indonesia, antara lain; pergerakan demokrasi kewarganegaraan yang menghindarkan rakyat Mesir di bawah pimpinan Zaghul Pasha.

Pergerakan rakyat India di bawah pimpinan Tilak dan Gandhi melawan ketamakan asing, serta Tiongkok menjatuhkan absolutisme Manchu dan melawan Imperialisme Barat. Kemenangankemenangan yang diperoleh oleh setiap negara tersebut telah menyadarkan hebatnya kekuatan bersama. Perlawanan tersebut menjadi inspirasi rakyat pribumi untuk melakukan perlawanan terhadap penjajah Belanda.

Pergerakan nasional pada abad 20 menunjukkan adanya rasa nasionalisme yang tinggi. Setiap organisasi yang dibentuk memiliki visi, misi dan tujuan yang jelas (Michael Addas, 1988: 42). Pergerakan tidak lagi berdasarkan tuan dan hamba, melainkan merupakan kesadaran pribadi sebagai bangsa yang dijajah. Kesadaran seperti perasaan senasib, sepenanggungan, dan persamaan identitas menjadi dasar perkumpulan. Dasar perkumpulan tersebut kemudian melahirkan keinginan untuk selalu berpartisipasi dalam perkumpulan.

Penggunaan media masa sebagai sarana komunikasi menjadi pembentuk dan pengembang hubungan perseorang dengan rakyat mengenai suatu konsepsi pergerakan nasional. Hampir setiap orang, maupun kelompok membujuk kelompok lain menerima gagasan, usaha, perjuangan, ideologi yang dipercayainya efektif mencapai tujuan kemerdekaan. Lebih jauh, komunikasi melalui media massa juga berupaya membuat orang ataupun kelompok bertindak sesuai yang dituliskannya (Suryo Mihardjo, 2002: 41).

Kesadaran ini, semakin tumbuh dengan lahirnya golongan terpelajar yang mempertanyakan struktur yang selama ini melingkupi rakyat pribumi yang semakin menderita dibawah modernisasi yang dibawa oleh bangsa Barat (Djoko, 2008: 23). Perjuangan menyebarkan cita-cita bangsa Indonesia pada masa itu, juga menunjukkan adanya hubungan moral pers dan rakyat (Andi Baso, 1993: 12). Oleh karena itu, dapat dikatakan bahwa pers Indonesia pada masa itu merupakan parlemen masyarakat untuk mengemukakan hal-hal yang ditentang olehnya. Isi surat kabar merupakan refleksi dari isi hati rakyat yang mendorong masyarakat melakukan pergerakan memperbaiki nasib.

Rubrikasi yang terdapat dalam pers di bawah kaum pergerakan senantiasa menunjukkan adanya usaha-usaha menyadarkan rakyat tentang kemajuan dan pergerakan. Pergerakan melalui bidang politik, sosial, dan ekonomi. Salah satu tokoh yang mengawali peran pribumi sekaligus menjadi pelopor penerbitan surat kabar masa itu adalah Koesoemo Oetoyo. Oetoyo merupakan redaktur Pewarta Priyayi, yang di terbitkan oleh Asperen van 
der velde Press di Semarang setiap tiga bulan sekali (I Taufik, 1993: 25). Surat kabar ini masih bersifat cooperatif dengan pemerintah Hindia Belanda. Sifat kooperatif membuat isi dari berita cenderung memberikan informasi yang tidak bertentangan dengan pemerintah. Meskipun demikian, pewarta priyayi memiliki arti dalam sejarah pergerakan bangsa (Ahmat B Adam, 1955: 93).

Gagasan tentang keterbukaan yang kerap kali disebarkan Oetoyo melalui Pewarta Priyayi memunculkan keterbukaan priyayi lama untuk berkumpul menjadi organisasi pergerakan dikemudian hari.

\section{B. Koesoemo Oetoyo}

Oetoyo lahir pada tanggal 13 Januari tahun 1871, secara garis besar merupakan keturunan priyayi Jawa. Ayah Oetoyo, Raden Mas Soejoedi Soetodikoesoemo (patih di Pekalongan). Ibunya, Raden Ayu Soeratinem merupakan keturunan Raden Adipati Aroeng Binang (Bupati Kebumen). Sedangkan, kakek dari garis ayah, Raden Mas Soerokoesoemo adalah Bupati Kutoarjo, dan masih keturunan Sultan Hamengku Buwono I.

Oetoyo merupakan anak kedua dari tiga bersaudara, kakak bernama Raden Mas Oemar Soerodikoesoemo, sedangkan adek bernama Oetaryo. Berasal dari keturunan Priyayi tidak membuat Oetoyo bersifat ekslusif, karena sejak kecil ia menunjukkan sikap terbuka dengan bergaul dengan siapapun tanpa membedakan kelas sosial.
Garis keturunan ini juga menjadi modal sosial Oetoyo untuk mampu mengenyam pendidikan.

Oetoyo berhasil di bidangnya sebagai tokoh pergerakan dengan mendirikan Dewan Kabupaten pada tahun 1917 yang mendorong munculnya Dewan Rak'jat (Volksraad) di kemudian hari (Shirashi takashi, 1997: 36). Sebagai ketua Budi Utomo, ia berhasil menghimpun kekuatan besar dengan membentuk fusi menjadi Parindra. Sebagai Jurnalis, ia berkarya dalam beberapa surat kabar Ilmoe Tani, Pewarta Priyayi dan kabar Perniagaan, yang dikemudian hari menginspirasi tokoh pergerakan lain untuk menyuarakan aspirasi rakyat melalui media massa.

Oetoyo juga berhasil memegang teguh etiket dan etika sosial, dibuktikan melalui perannya dalam Badan Pensensoran Film bersama Mariah Ulfa Santoso. Oetoyo menerbitkan karya-karya monumental, ia menerjemahkan lima buku karya Frederick Holle mengenai pertanian dan kesejahteraan petani.

Buku terjemahannya ini menjadi solusi dalam menyelediki, mengatasi masalah penanaman, gagal panen, dan menjadi dasar diberlakukannya politik etis dengan salah satu fokusnya pada irigasi (Daliman, 2012: 73). Oetoyo juga menerjemahkan dokumen perundangundangan pada masa Hindia Belanda ke dalam bahasa Jawa. Oetoyo sebagai jurnalis menyebarkan gagasannya mengenai 
pentingnya Dewan Desa, pendidikan, kesejahteraan rakyat, serta mengonsep pergerakan nasional yang relevan hingga masa sekarang.

Oetoyo mempunyai pengaruh pada masyarakat di zamannya, ia dikenal sebagai penganut demokrasi yang pandai bernegosiasi dan diplomasi (Gamal Komandoko, 2008: 20). Oetoyo dipercaya sebagai diplomat yang banyak berjasa dalam membangkitkan semangat melawan penjajah, dibuktikan dengan mosi-mosi yang dikeluarkannya dalam volksraad untuk menuntut perbaikan kondisi sosial, kesejahteraan rakyat dan keterlibatan rakyat dalam politik.

Pendapat Oetoyo juga dijadikan dasar pengambilan keputusan oleh tokohtokoh pergerakan seperti; $\mathrm{Ki}$ Hadjar Dewantara, Soekarno, Mohammad Hatta. Oetoyo layak disebut tokoh sekaligus ditokohkan. Perjuangannya dalam pergerakan nasional Indonesia melalui segala daya, upaya, hingga akhir hayatnya merupakan bukti perjuangan membebaskan bangsa dari penjajahan. Sebagai seorang yang memiliki kekuasaan, ia berupaya membela wong cilik yang merupakan inferior dan tertindas pada masa feodal (Suhartono, 2005: 204).

Oetoyo menjunjung budaya bangsa dan menanamkan rasa nasionalisme kepada generasi penerus hingga akhirnya menggerakkan seluruh lapisan masyarakat untuk bersatu melawan ketidakadilan bangsa Barat. Oetoyo merupakan salah satu tokoh dari golongan tua yang memiliki keterbukaan sifat dan pemikiran untuk memajukan bangsa dengan mengonsep pergerakan nasional yang ideal. Oetoyo pada mulanya merupakan pendukung politik etis pemerintah Hindia Belanda, karena dalam pemikirannya golongan terpelajar meruapakan tombak yang menciptakan perubahan di masyarakat.

Tentu saja konteks mendukung disini berbeda dengan konsep politik etis masyarakat. Oetoyo mendukung sepenuhnya untuk kepentingan rakyat, yaitu kebebasan menegnayam pendidikan. Sedangkan pemerintah berdasarkan pada kepentingan negeri induk, yaitu menjajah. Oetoyo kemudian memiliki konsep pergerakan nasional yang ideal dalam bidang politik, sosial, dan ekonomi yang memberikan corak baru dalam pola pergerakan di Indonesia.

\section{Metode Penelitian}

Metode penelitian sejarah merupakan seperangkat aturan dan prinsip sistematis untuk mengumpulkan sumbersumber sejarah secara efektif, kemudian menilaisecara kritis, dan mewujudkan dalam bentuk tulisan sejarah. Berikut langkah-langkah yang dilakukan peneliti:

\section{A. Pemilihan Topik}

Pemilihan topik didasarkan dua pokok, yaitu kedekatan emosional dan kedekatan intelektual. Pemilihan topik 
berdasarkan dua alasan tersebut, akan mempermudah proses penelitian yang sedang dikaji oleh peneliti, sehingga peneliti akan bersungguh-sungguh dalam meneliti dan menganalisis topik penelitian. Kedekatan emosional merupakan subjektifitas sejarah atas topik yang dipilih.

Subyektifitas berkaitan dengan perasaan, emosi, keturunan, kewilayahan terhadap permasalahan yang dikaji dan cenderung berat sebelah (Louis Gottschalk, 2008: 39). Alasan emosional peneliti adalah adanya kesenangan dalam menganalisis tokoh, sedangkan Oetoyo dipilih karena pemikirannya mengenai pergerakan nasional merupakan gagasan yang berbeda pada masa itu.

Ketersediaan sumber juga menjadi alasan dan motivasi peneliti tertarik untuk mengkaji lebih dalam mengenai pemikiran dan peranan Oetoyo dalam pergerakan nasional.Kedekatan Intelektual bersifat obyektif, meskipun tidak jarang emosi sering berpengaruh pada intelektualitas. Kedekatan intelektual yang melatar belakangi pemilihan topik berkaitan dengan upaya mengaplikasikan pemahaman sejarah pemikiran.

\section{B. Pengumpulan sumber(Heuristik)}

Pengumpulan sumber yang dilakukan peneliti berupa sumber primer dan sekunder. Sumber primer, hasil tulisan atau catatan yang sejaman dengan peristiwa/kejadian (Suharto, 2010:11). Sumber sekunder, kesaksian dari siapapun yang bukan merupakan saksi pandanganmata, yakni dari seseorang yang tidak hadir pada peristiwa yang dikisahkannya (Louis Gottschallk, 2008: 43). Sumber primer yang digunakan dalam penelitian ini, antara lain;

Afschrift-Mailrapport. Weltevreden, den 6 November $1928 \quad$ GeheimEigenhandig.

Kabinet Vertaal 18 Juni 1938 Het Vergoderrech. Jakarta: ANRI. Tidak diterbitkan

Koentjoro Poerbopranoto. (1937). Dewan Ra'jat: (Volksraad). Batavia: Balai Poestaka.

Koesoemo Oetoyo. (1931). 5de Vergadering -Woensdag 8 Juli 1931. Ingkomen stukken-Voorbehond van behandeling door den volksraad van ond.21mededeeling van den voorzitter betreffende benoeming van Commissies- Begrooting van Nederlandsch-Indie voor 1932,algemeene beschouwingen (ond).1. Batavia : Volksraad.

Koesoemo Oetoyo. (1931). 20ste Vergadering-Woendag 29 Juli 1931. Avondvergadering Begrooting van Nederlandsch-indie 1932 (ond.1), Algemeene beschouwingen. Batavia: Volksraad.

Koesoemo Oetoyo. (1934). 12de vergadering-Vrijdag 18 Juli 1934. Ingkomen stuk,-Begrooting van Nederlandsch-Indie voor 1935 (ond.1), algemene gedeelte. Batavia: Volksraad.

Koesoemo Oetoyo. (1934). 35ste Vergadering-Mandag 18 Agustus 1934. Begrooting van NederlandschIndie voor 1935 (ond.1), algemeen gedeelte, moties. Batavia: Volksraad.

Koesoemo Oetoyo. (1934). 36 ste vergadering-Dinsdag 14 Agustus 1934. Begrooting van Nederlandsch Indie voor 1935 (ond.1), afd. VI, departement van Economische Zaken, met afd VIA-D, algemeen gedeelte.

Koesoemo Oetoyo. (1936). 56ste Vergadering-Doenderdag 23 Januari 
1936. Suikerregelingen 1936 (ond 100). Batavia: Volksraad.

Koesoemo Oetoyo. (1952). "KenangKenangan Pengalaman Saja", dari Kebangkitan Nasional Sampai Proklamasi Kemerdekaan. Jakarta: Pustaka penerbit Endang.

Kortsamenvattend Overzicht der besprekinen op het Boedi-Oetomo Conggres, Gehouden op 31 Desember en 1 Januari 1928 te Jogjakarta. Jakarta: ANRI, Tidak Diterbitkan.

Politiek Politionel Overzicht Januari 1928, Jakarta: ANRI, Tidak diterbitkan

Tweede Congres der P.P.P.K.I Eerste vergadering 25 Desember 1929 avonds 9 uur in de societeit Habiprojo.

Verslag van het 23ste congres van Beodi Oetomo, gehouden te Semarang van 3 tot 5 Juni 1933.

Verslag betreffende het 20ste Congress Van Boedi Oetomo op 23-24 Desember 1929, Jakarta: ANRI, tidak diterbitkan.

Verslag van Het Negenti Ende BondsCongress Van Boedi Oetomo, gehoulden tot Soerakarta van 6 tot 9 April 1928.

Vertaling. Verslag der besloten vergaderingen tijdene het congres van Boedi-Oetomo, gehoulden te Djokdjakarta van 31 December 1927 tot en met 1 Januari 1928.

Sumber sekunder yang digunakan

dalam penelitian ini, sebagai berikut:

Akira Nagazumi. (1997). Bangkitnya Nasionalisme Indonesia: Budi Utomo 1908-1913. Jakarta: Pustaka Utama Grafiti.

Gamal Komandoko.(2008). Boedi Oetomo: Awal Bangkitnya Kesadaran Bangsa. Yogyakarta: Media press.

Pitut Soeharto. (1981). Cahaya di Kegelapan: Selecta Kedua Boedi Oetomo \& Sarekat Islam Pertumbuhan dalam Dokumen Asli. Jakarta: Jaya Sakti.

Ramadhan K H. (2008). Perjalanan Panjang Anak Bumi : Biografi R.M.A.A Koesoemo Oetoyo. Jakarta: Obor.
Sartono Kartodirdjo. (1972). Kolonialisme dan Nasionalisme di Indonesia pada Abad 19 dan Abad 20. Yogyakarta: Seksi Peneliti Djurusan Sejarah Fakultas Sastra dan Kebudajaan UGM.

Suhartono. (2001). Sejarah Pergerakan Nasional: Dari Budi Utomo sampai Proklamasi 1908-1945. Yogyakarta: Pustaka Pelajar.

Wawancara dengan Atas Hendartini Habsyah, pada tanggal 25 Agustus 2016 di Hotel Tentrem Yogyakarta, pukul 19.00 WIB

\section{Kritik Sumber (Verivikasi)}

Kritik sumber diperlukan agar terhindar dari fantasi, manipulasi atau fabrikasi (Suhartono, 2010: 35). Peneliti menggunakan kritik ekstern, untuk melihat keaslian sumber. Keaslian sumber dapat dilihat dari segi bentuk, bahan, tulisan, dan penggunaan bahasa. Sedangkan kritik intern, untuk menguji kredibilitas sumber. Aspek utama diperhatikan dalam kritik intern adalah konten/isi sebuah sumber.

Peneliti melakukan kritik ekstern dengan melihat kapan, dimana, siapa yag membuat sumber, dari bahan apa tulisan, koran, foto, maupun tulisan dibuat, serta apakah sumber dalam bentuk asli. Aspek utama yang diperhatikan adalah kondisi fisik. Beberapa sumber yang diperoleh peneliti dalam kondisi rusak dan kurang dapat dibaca dengan jelas. Hasil peneliti dalam melakukan kritik intern, ditemukan informasi kurang lengkap dalam sumber yang diperoleh. Karya Oetoyo yang berjudul Kenang-Kenangan Pengalaman Saja", dari Kebangkitan Nasional Sampai Proklamasi 
Kemerdekaan ditulisnya saat berusia lanjut, sehingga kurang begitu jelas dalam menggambarkan konsep pergerakan nasional menurutnya.

\section{Penafsiran (Interpretasi)}

Interpretasi dalam konteks sejarah dapat dibedakan menjadi dua macam, yakni analisis dan sintesis. Analisis berarti menguraikan. Sumber yang bervariasi yang telah diperoleh diuraikan, hal ini dilakukan mengingat sumber sejarah terkadang mengandung berbagai kemungkinan di dalamnya.

Sedangkan yang dimaksud dengan sintesis adalah melakukan penyatuan. Sumber-sumber yang telah terkumpul, kemudian disatukan menjadi fakta sejarah yang akurat. Peneliti dalam hal ini melakukan proses analisis dan sintesis dalam mengkomunikasikan hasil penelitian.

\section{E. Penulisan Sejarah (Historiografi)}

Penulisan sejarah merupakan proses menyajikan data yang telah diseleksi dan intepretasi kedalam tulisan yang bersifat kritis, analitis, dan ilmiah agar dapat dipertanggungjawabkan. Penulisan sejarah berdasarkan konsep kronologi terdiri dari tiga bagian yaitu pendahuluan, isi, dan penutup. Penelitian ini juga menggunakan pendekatan agar lebih mampu melakukan eksplanasi sejarah yang tidak hanya terbatas pada narasi apa dan siapa (Sartono K, 1992: 4). Pendekatan dalam penelitian sejarah dapat dilakukan dengan kajian teks, kajian konteks sejarah, dan kajian hubungan antara teks dan masyarakatnya (Hariyono, 1995:97-98). Pendekatan yang digunakan oleh penelitian adalah Pendekatan politik yang menekankan pada komunikasi politik. Komunikasi politik diartikan sebagai proses komunikasi yang memiliki implikasi atau konsekuensi terhadap aktifitas politik dan juga memiliki pesan yang bermuatan politik (Hafield Cangara, 2014: 14). Komunikasi dalam politik lebih dikenal dengan propaganda (Nurudin, 2001: 9).

Teori yang digunakan adalah teori interaksi kepribadian kepemimpinan politik (Dan Nimmo, 1998: 39). Teori interaksi kepribadian kepemimpinan politik dapat menggambarkan bagaimana waktu, tempat, keadaan, dan interaksi menentukan siapa yang memimpin dan siapa pengikutnya, menggambarkan bagaimana kepribadian para pemimpim (faktor yang bertalian dengan kepemimpinan), serta pengharapan dan kebutuhan dari pengikutnya.

$$
\text { Pendekatan komunikasi politik }
$$
dengan teori interaksi kepribadian kepemimpinan politik digunakan untuk menjelaskan bagaimana Oetoyo menggagas pergerakan nasional sesuai dengan situasi, semangat zaman, tempat dan politik pada saat itu. Bagaimana menggunakan pengaruhnya untuk mempengaruhi kelompok lain dalam mendukung gagasannya dalam pergerakan nasional. Teori ini juga digunakan untuk menjelaskan bagaimana Oetoyo menyebarluaskan gagasannya ke dalam lingkungan sosialnya. 
Penelitian ini juga menggunakan teori komunikasi fungsional untuk melihat tujuan dan cara mencapai tujuan politik (Deliar Noer, 1995: 6). Teori ini menggambarkan akibat komunikasi massa terhadap organisasi sosial, cara orang menata persepsinya dan apa akibatnya. Secara umum fungsi komunikasi secara fungsional digunakan untuk alat penerangan, perubahan dan pengontrol.

Pendekatan komunikasi politik dengan teori komunikasi fungsional digunakan untuk menjelaskan bagaiamana reaksi dari kelompok sosial maupun individu dalam menanggapi konsep pergerakan nasional yang digagas oleh Oetoyo. Perubahan apa yang terjadi di dalam pola pergerakan nasional Indonesia pada masa itu dengan adanya konsep pergerakan nasional Oetoyo, serta bagaimana dampaknya.

\section{Hasil Dan Pembahasan}

\section{A. Pandangan Koesoemo Oetoyo Tentang} Nasionalisme

Nasionalisme dalam pandangan Oetoyo merupakan paham yang di dasarkan pada kemauan setiap individu untuk menjaga dan melestarikan kebudayaan bersama, hidup bersama dalam satu tatanan masyarakat yang di dalamnya terdapat kesamaan dalam berbagai bidang kehidupan sebagai satu identitas (Koesoemo Oetoyo, 1952: 143-145). Satu identitas berarti tidak merujuk lagi pada satu etnis, ataupun satu daerah melainkan satu nation (Bangsa).

Pandangan tersebut ditulis dalam sebuah memoar yang juga memuat proses nasionalisme dalam menyatukan kekuatan rakyat, konsep Oetoyo juga relevan bila dilihat dengan teori identitas sosial, dimana setiap orang berdasarkan teori ini menyatakan perlu menjadi anggota kelompok dan idealnya mereka memandang (in group) lebih baik dari kelompok lainnya (Crish Barker, 2012: 221). Melihat konteks zaman pada masa itu, keinginan ini lahir karena kesadaran atas penderitaan yang disebabkan oleh pemerintah di negaranya sendiri. Konsekuensi dari pemikiran dan kondisi memunculkan kesadaran bahwa perampasan terhadap kemerdekaan ketidakadilan yang tidak dapat diterima.

Lebih jauh, Oetoyo menyatakan bahwa konsep nasionalisme yang ada di Indonesia harus berbeda dengan nasionalisme yang lahir di Barat (Atas Hendartini, 2016: wawancara). Nasionalisme Barat tidak boleh begitu saja dibawa dan ditiru di Indonesia. Menurutnya, konsep nasionalisme Indonesia merupakan lawan dari kolonialisme yang bertujuan membentuk negara merdeka. Hal ini jelas berbeda dengan yang ada di Barat. nasionalisme Barat didasari oleh pembelaan atas satu kepentingan kelompok melawan ketidakadilan, sehingga hal ini melahirkan etnosentrisme terhadap in group dan berujung pada lahirnya hasrat kolonialisme. 
Nasionalisme Barat dalam pandangan Oetoyo merupakan paham yang sangat pincang (Koesoemo Oetoyo, 1952: 152). Nasionalisme ini telah melahirkan etnosentrisme hingga lahir hasrat ingin menguasai dalam bentuk kolonialisasi. Sedangkan, dari sudut pandang Hindia Belanda hal itu tidak sesuai dengan kondisi sosial yang ada. Kecenderungan terhadap suatu daerah atau ideologi tertentu justru akan membuat politik pecah belah pemerintah Hindia Belanda semakin berhasil dan tidak akan terwujud satu kesatuan kelak kemudian hari.

Oetoyo menegaskan perlu membuka mata rakyat tentang identitas dan masa depannya, melalui penanaman nilai-nilai nasionalisme di kalangan pribumi (Rudolk Marziek, 2006: xvi). Oetoyo meyakini bahwa Identitas diri akan mengembalikan kebanggaan yang telah luntur akibat modernitas Barat, sehingga melahirkan perkumpulan dan kesatuan dari berbagai golongan di Hindia Belanda.Sarana untuk menanamkan nilai-nilai nasionalisme yang efektif menurut Oetoyo adalah pendidikan.

Dalam memoarnya Oetoyo menuliskan apa yang harus dilakukan oleh generasi tua untuk generasi muda sebagai ujung tombak pergerakan. Tulisan tersebut berbunyi "Laat Ons Onze kinderen een goede opleding geven, opdat zij later in staat zullen zijn hun eigen huishhouding goed te regelen!"(Koesoemo Oetoyo, 1952: Tidak diterbitkan).Terjemahan dalam bahasa
Indoensia, sebagai berikut "Bergeraklah supaya bisa memberi didikan yang sempurna kepada anak-anak kita, biar akhirnya bisa mengurus rumah tangga kita sendiri!".

Sebagai bentuk kritikannya, Oetoyo mengorientasikan paham nasionalisme dengan cara non-kooperasi terhadap budaya Barat yang tidak sesuai kepribadian bangsa. Nasionalisme Indonesia harus merupakan kepercayaan terhadap kecerdasan dan kemampuan diri sendiri, kemauan bersama menciptakan penentuan nasib sendiri, dan kepemilikan kebudayaan nasional.

Orientasi ini dikemudian hari melahirkan konsep pergerakan nasional yang menurut Oetoyo harus dilakukan dengan cara perkumpulan/organisasi, perbaikan status sosial (kesejahteraan sosial dan pendidikan), serta diplomasi bukan lagi dengan kepercayaan terhadap adanya ratu adil (Silawati Hartian, 1992: 124). Pandangan tentang nasionalisme membuat oetoyo kemudian mengonsep pergerakan nasional yang sesuai dan ideal untuk perjuangan rakyat.

\section{B. Konsep Pergerakan Nasional Koesoemo Oetoyo}

Menurut Atas Hendartini Habsyah, pergerakan nasional dalam pandangan Oetoyo merupakan usaha yang harus dilakukan dengan penuh kesadaran untuk menyatukan seluruh lapisan, tanpa kecenderungan terhadap satu kepentingan 
kelompok tertentu agar tercapai kemerdekaan. Pandangan demikian, tidak dapat dipisahkan dari pandangannya mengenai nasionalisme Indonesia. Nasionalisme dalam pandangan Oetoyo terkait erat dengan self-government, kemauan bersama, dan budaya Indonesia sebagai identitas nasional yang di dorong oleh faktor kontekstual seperti moderniasasi, industrialisasi dan edukasi.

Menurut Oetoyo, modernisasi, industrialisasi, dan edukasi merupakan faktor kontekstual yang mendorong adanya pergerakan nasional (Anthony D Smith, 1971: 110). Industrialisasi mengakibatkan adanya krisis dalam elit priyayi lama dalam hal jabatan. Posisi ini tidak bisa ditempati oleh sembarang bangsawan, karena seiring bertumbuhnya industrialisasi maka rasionalisasi birokrasi dilakukan. Rasionalisasi birokrasi berdampak pada munculnya elit baru terpelajar sebagai pegawai birokrasi yang berpikiran lebih modern.

Oetoyo berpandangan munculnya elit baru merupakan langkah penggerak adanya pemikiran-pemikiran ke arah kemerdekaan (Dharmono Hadjowidjono, 2008: 354). Kemunculan golongan ini sekaligus mendorong adanya pandangan baru untuk priyayi lama. Priyayi lama mulai mengikuti cara priyayi baru dengan mendirikan perkumpulan. Meskipun, perkumpulan yang dibuat oleh generasi tua bersifat ekslusif di kalangan priyayi jawa saja. Namun hal ini merupakan langkah awal yang dapat menumbuhkan kesadaran setiap kelompok untuk berkumpul membela kepentingan bangsanya sendiri.

Konsepsi diatas memperkuat pandangan Oetoyo tentang pergerakan nasional yang bisa dilakukan dengan upaya modernisasi, industrialisasi dan edukasi melalui bidang politik, sosial, dan ekonomi. Tentu saja dalam hal ini berdasarkan kekuatan sendiri, kemampuan sendiri dan tidak berdasarkan atas satu kepentingan saja (Atas Hendartini, 2016: wawancara). Politik, sosial, dan ekonomi merupakan satu kesatuan yang selalu berkaitan sehingga ketika semuanya berada pada posisi baik, kesejahteraan akan tercapai. Tercapainya kesejahteraan menandai adanya kemampuan untuk berdiri sendiri sebagai suatu bangsa yang terdirik, berdaulat dan mampu mengsejahterakan rakyat.

Oetoyo berpendapat untuk memerdekakan rakyat pribumi, dapat dilakukan dengan tidak mengikuti ideologi tertentu. Ideologi tertentu hanya akan menimbulkan kecenderungan tertentu. Kecenderungan tertentu ditakutkan akan menimbulkan perjuangan yang hanya mengarah pada pencapaian tujuan kelompok tertentu, dan pertentangan dengan kelompok lain (Frank Dhont, 2005: 10). Padahal salah satu penguat pergerakan adalah kemauan bersama. Hal ini membuat Oetoyo menolak adanya kecenderungan terhadap suatu ideologi tertentu. Konsepsi 
itulah yang kemudian membentuk pandangan Oetoyo dalam mengonsep cara pergerakan nasional yang ideal.

Pergerakan nasional dalam konsep pemikiran Oetoyo merupakan usaha perbaikan dalam segala aspek kehidupan seperti politik, sosial, dan ekonomi (Achmad Djajadiningrat, 1936: 324). Pada bidang politik dilakukan dengan membuka kesempatan sebesar-besarnya agar rakyat pribumi mampu berpartisipasi dalam politik. Pada bidang sosial dilakukan dengan upaya meningkatkan martabat bangsa, dan membangun kesadaran serta kesatuan identitas bangsa. Sedangkan pada bidang ekonomi dilakukan dengan mensejahterakan rakyat. Konsep pergerakan Oetoyo yang digagas Oetoyo cenderung pada cara-cara diplomasi, bukan dengan radikalisme, sesuai dengan perkembangan zaman yang di bawa oleh orang Barat.

Konsep pergerakan nasional yang digagas Oetoyo merupakan pemikiran yang revolusioner pada masa itu. Mengingat kalangan Bupati Jawa cenderung berpihak pada pemerintah dan kurang mendukung usaha generasi muda menyuarakan nasionalisme maupun pergerakan nasional. Meskipun konsep yang diusung Oetoyo tidak memperoleh dukungan dari generasi muda yang menilai konsep tersebut tidak progresif dan revolusioner. Gagasan ini tetap memberikan corak pada pergerakan Indonesia dan menjadi gagasan momentum sekaligus stimulus munculnya ide-ide membebaskan diri dari penjajahan yang menginspirasi generasi penerus.

Ciri yang menjadikan konsep pergerakan nasional Oetoyo perlu dipertimbangkan terletak pada pemilihan cara yang digunakan. Meskipun, bila dipandang dari sudat pandang sempit generasi muda, konsep Oetoyo ini dinilai sebagai usaha pergerakan yang bersifat moderat.Namun bila dilihat dari perkembangannya konsep pergerakan nasional Oetoyo ini menjadi konsep yang dapat digunakan dalam kondisi dan waktu yang lama dan berkelanjutan. Ketika konsep pergerakan nasional yang diusung oleh intelektual muda memunculkan gagasangagasan yang ekstrim dan bersifat radikal, konsep Oetoyo menjadi solusi dalam menyatukan perpecahan tokoh pergerakan melalui ide-ide berfusi membentuk partai politik sebagai wakil rakyat (Achmad Djajadiningrat, 1936: 254).

Ciri lain yang menjadikan konsep pergerakan nasional Oetoyo istimewa adalah gagasan Oetoyo tentang pergerakan nasional merupakan satu kesatuan usaha perbaikan dalam semua bidang, yaitu sosial, ekonomi, dan politik. Ketiganya tidak dapat dipisahkan dan merupakan satu kesatuan yang harus sejalan. Hal ini menjadi satu pengikat kesatuan nasional sebagai wujud terbentuknya bangsa dikemudian hari (W Poespoprojo, 1986: 28). 


\section{Konsep Pergerakan Nasional Oetoyo Dalam Politik}

Politik dipandang Oetoyo sebagai sarana mencapai tujuan dan kekuasaan. Politik merupakan tempat menyuarakan aspirasi rakyat sehingga hak-hak warga negara akan terpenuhi. Hal ini sangat berbeda dengan kondisi rakyat masa iyu yang hanya menjadi objek dari kebijakan politik, sehingga wajar bila keikutsertaan rakyat pribumi dalam politik dianggap solusi untuk mengubah kondisi itu. Oetoyo berpandangan bahwa politik tidak akan dapat dipisahkan dari hukum, kekuasaan dan hak. Hukum, kekuasaan dan hak itu harus diarahkan pada tujuan pemberian kesejahteraan agar mampu mewujudkan kemerdekaan sebagai wujud politik yang adil.

Konsep pergerakan nasional yang digagas oleh Oetoyo berpengaruh terhadap konsep pergerakan nasional yang dilakukannya dalam bidang politik. Jika secara umum Oetoyo menggambarkan pergerakan nasional merupakan upaya perbaikan dalam segala bidang seperti politik, sosial dan ekonomi sebagai satu kesatuan yang tidak dapat dipisahkan. Maka dalam pergerakan politik, Oetoyo mengarahkan perjuangannya pada upaya membentuk kebijakan yang mendorong kemandirian, pemberian otonomi, kesejahteraan dan peningkatan martabat rakyat pribumi. Pergerakan nasional dalam bidang politik dilakukan dengan kritik terhadap kebijakan pemerintah yang dianggap bertentangan melalui proses diplomasi.

$$
\text { Oetoyo menganggap bahwa }
$$
tindakan dengan menentang pemerintah secara langsung dan usaha dengan angkat senjata bukanlah jalan yang tepat dan efektif. Berdasarkan pengalaman masa lalu rakyat pribumi yang berperang dengan menganggakat senjata lebih mudah dipatahkan oleh pemerintah.

Menurut Oetoyo cara-cara diplomasi merupakan cara yang tepat untuk mengalahkan musuh secara perlahan. Oetoyo meyakini cara diplomasi akan memudahkan menganalisis bagaimana pengambilan sikap pemerintah Hindia Belanda, memperoleh dukungannya dan bahkan mengelabui pemerintah dengan berpura-pura bersifat kooperatif (Ramadhan K H, 2008: 9).

Oetoyo semakin menunjukkan kecemerlangan pemikiran dalam mengagas pergerakan dibidang politik. Ia mengagas langkah-langkah yang seharusnya diambil dan diperjuangkan melalui politik, yaitu: Pertama, kebebasan berserikat dan berorganisasi (Koesoemo Oetoyo, 1932: 39) Didirikannya organisasi sangatlah perlu, hal ini bertujuan untuk mengimbnagi dominasi Barat. Nasib rakyat yang selama ini hanya sebagai objek berlakunya sistem administrasi dan politik Hindia Belanda akan terimbangi. Selain itu melalui 
organisasi rakyat akan memiliki penyeru kepentingan dan aspirasi rakyat.

Kedua, rakyat harus memiliki kebebasan dalam mengutarakan pendapat melalui tulisan maupun lisan. Konsepsi ini membuat Oetoyo mengkritik ordonansi pembredelan pers (Mien Joebhar, 2003; 279). Oetoyo memandang bahwa pers sebagai media penerangan dapat menyebarluaskan gagasan-gagasan kemajuan, dan sebagai pengontrol kesewenangan penguasa. Sedangkan pemberangusan pers dipandang sebagai usaha pihak berkuasa untuk terus berwenang atas pers dan rakyat.

Ketiga, hak rakyat untuk berkumpul dan mengeluarkan pendapat harus dilindungi, pemerintah Hindia Belanda tidak boleh sewenang-wenang dalam menghukum rakyat tanpa adanya aturan yang jelas dan kekerasan (48ste Vergadering Mandag, 1930: -). Gagasan ini muncul sebagai reaksi Oetoyo terhadap tindakan pemerintah Hindia Belanda yang semenamena terhadap tokoh pergerakan dan dalam pengadilan. Oetoyo menggambarkan kondisi masa itu, sebagai berikut:

...akan tetapi kalau perlu tidak segan akan mengutjapkan crietiek terhadapnja, maka banjak anggauta ${ }^{2}$ nja jang dapat rintangan dari pembesar ${ }^{2}$ pemerintah. Djika mereka berapat senantiasa mereka diawaskan oleh polisi dan barang siapa dengan pedas berani mentjela aturan ${ }^{2}$ pemerintah atau pembesar²nja maka mereka mendapat rintangan $\mathrm{rupa}^{2}$ dalam pekerdjaannja se-hari². (Koeseomo oetoyo, 1931: 45).
Oetoyo sebenarnya sudah mulai mengeluarkan gagasan tentang sistem pemerintahan di Hindia Belanda sejak tahun 1907. Oetoyo pada masa itu bersikeras agar pemerintah memberikan hak kepada rakyat pribumi untuk bersuara dan ikut menentukan jalannya pemerintahan dengan cara mendirikan sebuah Dewan Rakyat. Sayangnya pemerintah kurang terbuka dengan ide ini. Pandangan Oetoyo tersebut digambarkan sebagai berikut:

...bahwa ra'jat anak negeri mesti mendapat pengertian jang sempoerna tentang autonomi dan zelfbestur (pemerintah sendiri) dan mesti menjadi tahoe mengerdjakannja dengan berangsoer-angsoer. Ra'jat itoe mesti beladjar toeroet tjampoer mengoeroes keperloeannja sendiri. Sebab itoe djanganlah ra'jat itoe dikedjoetkan dengan matjam-matjam barang. Jang semata-mata asing kepadanja, jang tidak ia mendapat jelasnja tidak ia mengerti! Disinipoen hendaklah diingat sjarat bahwa kita tidak haroes menjorongnjorongkan kepada ra'jat itoe barang jang tidak hendak sesoeai dengan sifat tabi'atnja, melainkan sebaliknja kita haroes memberi djalan. Soepaja toemboh pengertian bahwa ra'jat sendiri akan diminta tjampor dalam oeroesan memboeat hoekoem dan melakoekan pemerintah (Koesoemo Oetoyo, 1931: 864)

Penolakan yang dilakukan oleh pemerintah Hindia Belanda, mendorong Oetoyo untuk mendirikan Dewan Kabupaten dan Dewan Desa di Jepara. Keputusan ini membuktikan besarnya tekad Oetoyo untuk membangun kesadaran rakyat pribumi agar berpartisipasi dalam pemerintahan. Tindakan ini sekaligus menunjukkan keinginan merubah Bupati 
lama agar lebih terbuka dengan pembaharuan. Pembaharuan tersebut terkait tugas Bupati dalam pergerakan nasional, yaitu mengayomi wong cilik. Hal ini dapat dilihat dariketegasan Oetoyo menyatakan"ciri keluhuran priyayi adalah komitmen mencintai wong cilik" (Shirashi Takhasi, 1997: 43).

Oetoyo menegaskan bahwa pergerakan nasional dibidang politik harus dapat menyatukan seluruh lapisan masyarakat. Hak politik harus di tangan rakyat, supaya rakyat dapat memperjuangkan hak, dan kepentingannya. Rakyat secara sadar harus mempunyai peranan yang sama untuk menghalangi dominasi Barat yang feodal. Mereka harus membentuk suatu partai politik yang dapat didukung bersama untuk menyuarakan aspirasinya (Putut Suharto, 1981: 219).

Berdasarkan teori interaksi kepribadian kepemimpinan politik, gagasan Oetoyo merupakan usaha memobilisasi rakyat dengan kepentingan politik bersama, menentang segala bentuk ketidakadilan kebijakan pemerintah Hindia Belanda secara bersama melalui penyatuan kekuatan.

Dewan Kabupaten pertama kali dibentuk Oetoyo di Jepara, tujuan dari pendirian Dewan Kabupaten adalah memberi nasehat kepada bupati (ramadhan K H, 2008: 109). Puncak dari keberhasilan pendirian Dewan Kabupaten, yaitu ketika Gubernemen secara resmi mendukung berdirinya Dewan Kabupaten di setiap kabupaten. Hal ini merupakan bukti bahwa pemikiran Oetoyo pada masa itu sangat progresif, dan memperluas kesempatan rakyat pribumi untuk ikut aktif dalam pemerintahan.

Achmad Djajadiningrat menjelaskan kewenangan yang dimiliki oleh Dewan kabupaten, antara lain mengatur dan memimpin pemerintahan dalam kabupaten bersama bupati, mempertahankan kebijakan kabupaten di hadapan gubernur jendral (Achmad Djajadiningrat, 1936: 396397). Dewan kabupaten dapat memebentuk panitia pelaksana (College van Gecommiteerden) untuk melaksanakan keputusan-keputusan yang telah dibuat.

Pembentukan ini membuat pemerintahan kabupaten terdiri dari bupati, dewan kabupaten dan panitia pelaksana. Pembentukan ini diharapkan dapat mengakomodir kepentingan rakyat. Dewan Desa yang dibentuk oleh Oetoyo bergerak di tingkat paling rendah, yaitu tingkat desa. Anggota dari Dewan Desa terdiri dari golongan pemuda.

Tujuan Oetoyo mendirikan Dewan Desa untuk menyadarkan pemuda tentang pentingnya ikut berpartisipasi dalam pemerintahan. Selain itu Oetoyo meyakini golongan muda dapat menjadi pengontrol kekuasaan yang ada di desa, dan lebih progresif ide-idenya (Ramadhan K H, 2008: 121). Dewan desa akan melaporkan kejadian-kejadian dan permasalahan yang 
segera membutuhkan solusi. Kesadaran ini dinilai akan menjadi tonggak keinginan setiap orang untuk mempercayai pemimpin politik, dan ikut mendukung serta berperan memperjuangkan kemerdekaan.

Oetoyo juga mengagas perlunya mendirikan perkumpulan dan menggabungkan diri dengan organisasi lain di bidang politik. Tujuan dari mendirikan perkumpulan atau menggabungkan diri adalah menghimpun kekuatan yang lebih besar, adanya kesatuan yang lebih kuat untuk mewakili aspirasinya.

Sebuah tulisan Oetoyo menengaskan bagaimana pentingnya berkumpul dan menggabungkan diri untuk mewujudkan kemandirian bangsa, yaitu ...Menimbang kurang perlunja berdiri sendiri, baik menjatuhkan diri dengan perkumpulan lain, supaja lebih kuat (Koesoemo Oetoyo, 1952: 143).

\section{Implikasi Konsep Pergerakan \\ Nasional Koesoemo Oetoyo}

Implikasi pemikiran Oetoyo dalam pergerakan nasional dapat dilihat dari pembaharuan-pembaharuan yang ada dalam lingkungan politik sosial, dan ekonomi masyarakat Indonesia. Gagasan Oetoyo mengenai makna nasionalisme, dapat diterapkan sebagai penguat bangsa hingga kini. Sedangkan pilihan cara untuk pergerakan nasional melalui politik, sosial, dan ekonomi dapat dijadikan alternatif dalam membangun bangsa yang maju di tengah pergaulan internasional. Pemikiran
Oetoyo memiliki arti penting dalam konteks masyrakat Hindia Belanda masa itu. Anak pribumi berpendidikan yang lahir karena usaha-usaha diplomasi politik, menjadi suatu simbol kebersamaan bagi pribumi terpelajar di Hindia Belanda. Simbol ini menggambarkan pentingnya keberadaan kelas baru terpelajar dalam mengubah nasib rakyat pribumi.

Simbol tersebut sekaligus menegaskan tujuan yang harus diperjuangkan dalam membebaskan rakyat dari penindasan kolonial. Hal ini penting mengingat transisi sistem pemerintahan Hindia Belanda menuntut anak pribumi mencari identitas baru. Oetoyo berhasil membentuk identitas tersebut, yaitu identitas sebagai kesatuan bangsa Indonesia. Gagasan Oetoyo tentang diplomasi terus berkembang sesuai konteks zamannya.

Pada era setelah Oetoyo, tokohtokoh yang menjadi wakil rakyat mulai menunjukkan peran penting dalam memajukan bangsa dengan cara-cara diplomasi. Diplomasi dianggap sebagai cara efektif menyelesaikan pertentangan antara dua kelompok untuk mencapai kesepakatan. Cara ini tidak hanya relevan untuk mengatasi permasalahan dalam negeri, melainkan juga urusan luar negeri. Bahkan hingga Indonesia merdeka, diplomasi merupakan cara paling efektif dalam ikut berpartisipasi dalam dunia internasional. 
Pemikiran Oetoyo tidak selalu memperoleh dukungan, salah satu perlawanan dari pemerintah (Ramadhan $\mathrm{K}, \mathrm{H}$, 2008: 141). Berikut gambaran tokoh pergerakan, "anak boeah tidak boeleh mendjawab perkataan kepalanja; melainkan apa jang dikatakan oleh kepala, ia menoeroet sadja, sebab kalau kepala soedah marah, anak boeah jang dimarahinja itoe dapat hoekoeman pasoeng di rumah kepala" (Jahja, $19 \mathrm{~J} \mathrm{H}$ Van Gigh, mengirim surat pada Gubernur Jendral di Buitenzorg, No. 648/p.z, tanggal 25 Juli 1924 yang berisi kecamanya terhadap gagasan Oetoyo. Edaran tersebut, berbunyi:

...R.M.T Koeoemo Oetoyo, yang katanya tidak terikat pada suatu ideologi apa pun, agaknya senang kalau di daerahnya ada kehidupan politik dalam masyarakat. Akan tetapi, seperti biasa, dalam keadaan demikian, kegiatan politik itu menjadi lebih meradang daripada sekedar pantas (Ramadhan $\mathrm{K} \mathrm{H}$, 2008: 135-140).

Tulisan tersebut memperoleh tanggapan Gubernemen dengan menyidang Oetoyo dan mengakhiri karirnya sebagai Bupati pada tahun 1925.

\section{Penutup}

\section{A. Kesimpulan}

Nasionalisme dalam pandangan Oetoyo merupakan paham yang di dasarkan pada kemauan setiap individu untuk menjaga dan melestarikan kebudayaan bersama, hidup bersama dalam satu tatanan masyarakat yang di dalamnya terdapat kesamaan dalam berbagai bidang kehidupan sebagai satu identitas. Pandangan ini membuat Koesoemo Oetoyo mengonsep pergerakan nasional yang ideal. Pergerakan nasional dalam konsep pemikiran Oetoyo merupakan usaha perbaikan dalam segala aspek kehidupan seperti politik, sosial, dan ekonomi.

Pada bidang politik dilakukan dengan membuka kesempatan sebesarbesarnya agar rakyat pribumi mampu berpartisipasi dalam politik. Pada bidang sosial dilakukan dengan upaya meningkatkan martabat bangsa, dan membangun kesadaran serta kesatuan identitas bangsa. Sedangkan pada bidang ekonomi dilakukan dengan mensejahterakan rakyat. Konsep pergerakan Oetoyo yang digagas Oetoyo cenderung pada cara-cara diplomasi, bukan dengan radikalisme.

Politik dipandang Oetoyo sebagai sarana mencapai tujuan dan kekuasaan. Politik merupakan tempat menyuarakan aspirasi rakyat sehingga hak-hak warga negara akan terpenuhi. Oetoyo menegaskan bahwa pergerakan nasional dibidang politik harus dapat menyatukan seluruh lapisan masyarakat. Oetoyo mengarahkan perjuangannya pada upaya membentuk kebijakan yang mendorong kemandirian, pemberian otonomi, kesejahteraan dan peningkatan martabat rakyat pribumi. 
Pergerakan nasional dalam bidang politik dilakukan dengan kritik-kritik terhadap kebijakan pemerintah yang dianggap bertentangan melalui proses diplomasi. Perjuangan dalam politik tidak boleh cenderung pada satu ideologi atau kepentingan melainkan harus berdasar pada kepentingan rakyat.

Implikasi pemikiran Oetoyo dalam pergerakan nasional dapat dilihat dari pembaharuan-pembaharuan yang ada dalam lingkungan politik sosial, dan ekonomi masyarakat Indonesia. Pemikiran Oetoyo memiliki arti penting dalam konteks masyrakat Hindia Belanda masa itu. Anak pribumi berpendidikan yang lahir karena usaha-usaha diplomasi politik, menjadi suatu simbol kebersamaan bagi pribumi terpelajar di Hindia Belanda. Simbol ini menggambarkan pentingnya keberadaan kelas baru terpelajar dalam mengubah nasib rakyat pribumi. Gagasan Oetoyo tentang diplomasi terus berkembang sesuai konteks zamannya.

Pada era setelah Oetoyo, tokohtokoh yang menjadi wakil rakyat mulai menunjukkan peran penting dalam memajukan bangsa dengan cara-cara diplomasi. Gagasan Oetoyo mengenai makna nasionalisme, dapat diterapkan sebagai penguat bangsa hingga kini. Sedangkan pilihan cara untuk pergerakan nasional melalui politik, sosial, dan ekonomi dapat dijadikan alternatif dalam membangun bangsa yang maju di tengah pergaulan internasional.

\section{B. Saran}

Perlu adanya perubahan cara memandang golongan tua dalam pergerakan nasional yang tidak hanya di dasarkan pada asumsi bahwa golongan tua adalah moderat sedangkan golongan muda revolusioner. Membiasakan peristiwa sejarah yang digenaralisir tanpa melihat konteks zaman dan sebagian dari yang umum, menjadikan pengetahuan sejarah tidak arif. Tidak mampu memberikan pandangan pada yang sebenarnya terjadi.

Sejarah adalah ilmu yang dinamis, sehingga pembaharuan dalam merekontruksi peristiwa merupakan suatu keniscayaan. Sejarah selalu mengajarkan pada masyarakat pendukungnya tentang pasca kebenaran, bagaimana seseorang akan mengambil keputusan setelah mengetahui suatu kebenaran, atau bagaimana kebenaran tersebut diterima, atau ditanggapi.

\section{Daftar Pustaka}

\section{Arsip:}

Jahja. 1930. 48ste Vergadering-Mandaag 27 Januari 1930. Eerste aanv.begrooting van Ned-Indie voor 1930; alg.beschouwingen. Batavia: Volksraad.

Koesoemo Oetoyo. 1934. 21ste Vergadering-Woendag 25 Juli 1934. Begrooting van Nederlandsch-Indie voor 1935 (ond.1), afd VI, departement van Economische Zaken met afdeling VI A-D. Batavia: Volksraad. 
Koesoemo Oetoyo. 1931. 5de VergaderingWoendag 8 Juli 1931. Begrooting van Nederlandsch-Indie voor 1932 (ond.1), algemeene beschouwingen. Batavia: Volksraad.

Koesoemo Oetoto \& M. H Thamrin. 1930. 48ste Vergadering-Mandag 27 Januari 1930. Eerste aanv, begrooting van ned,Indie voor 1930; alg.beschouwingen. Batavia: Volksraad

Koesoemo Oetoyo. 1931. 29ste VergaderingMaandag 10 Agustus 1931. Begrooting van Nederlandsch-Indie voor 1932 9ond.1), afdeling IV, departement van Binnenlandsch Bestuur. Batavia: Volksraad.

Koesoemo Oetoyo. 1936. 56ste Vergaderingdonderdag 23 Januari 1936. Suikerregelingen 1936 (ond.100). Batavia: Volksraad.

Mr.K.R.T Wongsoenegoro, Stellingen van den heer Mr. K.R.T Wongsoenegoro nader uit te werken en te verdedingen op het a.s Congres te Soerakarta. Soerakarta: Boedi Oetomo. Tanggal tidak terbaca

Tweede Congress der P.P.P.K.I Eerste Vergadering 25 Desember 1929's avonds 9 uur in de societeit Habiprojo. 1929. Surakarta: P.P.P.K.I.

Verslag der besloten vergadering tijdens het congres van Boedi-Oetomo, gehoulden te Djokjakarta van 31 December 1927 tot en met 1 Januari 1928. 1927. Djogjakarta: Boedi Oetomo.

\section{Buku:}

Achmad Djajadiningrat. 1936. KenangKenangan Pangeran Achmad Djajadiningrat. Djakarta: Balai Poestaka.

Addas, Michael. 1988. Ratu Adil: Tokoh dan Gerakan Milenarian Menentang Kolonialisme Eropa. Jakarta: Rajawali Press.

Ahmat B Adam. 1955. The Vernacular Press And The Emergence of Modern
Indonesian Consciousness 18551913. Ithaca: Cornell University.

Andi Baso M. 1993. Siaran Pers: Suatu Kiat Penulisan. Jakarta: Gramedia Pustaka.

Anhar Gonggong. 1988. Panorama Gerak Menuju Indonesia Merdeka. Jakarta: Departemen Pendidikan dan Kebudayaan.

Cahyo Budi Utomo. 1995. Dinamika Pergerakan Kebangsaan Indonesia dari Kebangkitan Hingga Kemerdekaan. Semarang: IKIP Semarang Press.

Cangara, Hafied. 2011. Komunikasi Politik: Konsep, Teori, dan Strategi. Jakarta: Rajawali Pers.

Daliman. 2012. Metode Penelitian Sejarah. Yogyakarta: Ombak.

Daliman. 2005. Sejarah Indonesia XIX-Awal Abad XX. Jakarta: Ombak.

Dan Nimmo. 1989. Komunikasi Politik: Komunikator, Pesan, dan Media. Bandung: Remaja.

Deliar Noer. 1995. Penghantar ke Pemikiran Politik. Medan: Dwipa.

Djoko Marihandono. 2008. Titik Balik Historiografi di Indonesia. Jakarta: Wedatama Widya Sastra.

Frank Dhont. 2005. Nasionalsime Baru Intelektual Indonesia Tahun 1920-An. Yogyakarta: UGM Press.

Gamal Komandoko. 2008. Boedi Oetomo: Awal Bangkitnya Kesadran Priyayi. Yogyakarta: Media Press.

Helius Sjamsudin. 2007. Metodologi Sejarah. Yogyakarta: Ombak.

I Taufik. 1977. Sejarah Perkembangan Pers di Indonesia. Jakarta: trinity Press.

Ingleson, John. "tanpa judul asli". Penerjemah. Zamakhsyari Dhofier. Penyunting. Ignas Kleden. 1988. Jalan ke Pengasingan; Pergerakan Nasionalis Indonesia Tahun 19271934. Jakarta: LP3ES.

Ki Hadjar Dewantara. 1952. Dari Kebangunan Nasional Sampai 
Proklamasi Kemerdekaan. Jakarta: Endang.

Koentjoro Poerbopranoto. 1937. Dewan Ra'jat (Volksraad). Batavia: Balai Poestaka.

Kuntowijoyo. 2005. Pengantar Ilmu Sejarah. Yogyakarta: Bentang Pustaka.

Louis Gottschalk. 2008. Mengerti Sejarah. Jakarta: Universitas Indonesia.

M. Gani. 1978. Surat Kabar Indoensia pada Tiga Zaman. Jakarta: Departemen Penerangan RI.

Nagazumi, Akira. "The Dawn of Indonesian Nationalism: The Early Years of the Budi tomo, 1908-1918". Penerjemah. KITLV-Lipi. 1989. Bangkitnya Nasionalisme Indonesia; Budi Utomo 1908-1918. Jakarta: Pustaka Utama Grafiti.

Nurudin. 2001. Komunikasi Propoganda. Bandung: Rosda Karya.

Putut Suharto. 1981. Cahaya di Kegelapan: Catatan Selecta Boedi Oetomo \& Sarekat Islam: Pertumbuhannya dalam Dokumen Asli. Jakarta: Jaya Sakti.

Pradipto Nirwandhono. 2011. Yang Ter (di) Lupakan: Kaum Indo dan Benih Nasionalisme Indonesia. Yogyakarta: Djaman Baroe.

Pringgodigdo. 1980. Sejarah Pergerakan Rakyat Indonesia. Jakarta: Dian Rakyat.

Ramadhan K H. 2008. Pejalanan Panjang Anak Bumi: Biografi R.M.A.A Koesoemo Oetoyo. Jakarta: Obor.

Ramlan Surbakti. 1992. Memahami Ilmu Politik. Jakarta: Grafindo.

Sartono Kartodirdjo. 1972. Kolonialisme dan Nasionalsime Indonesia Abad 19 dan 20. Yogyakarta: UGM Press.

. 1992. Pendekatan Ilmu Sosial dalam Metodologi Sejarah. Jakarta: Gramedia Pustaka Utama.

Silawati Hartian. 1992. Nasionalsime Menjelang Abad XX. Yogyakarta: Tiara Wacana.
Smith D Anthony. 1971. Theories of Nationalism. London: Duckworth.

Soebagijo. 1977. Sejarah Pers Indonesia. Jakarta: Dewan Press.

Sudiyo. 2002. Pergerakan Nasional Mencapai dan Mempertahankan Kemerdekaan. Jakarta: Rineka Cipta.

Suhartono. 2001. Sejarah Pergerakan Nasional: Dari Budi Utomo sampai Proklamasi 1908-1945. Yogyakarta: Pustaka Pelajar.

Suryo Mihardjo. 2002. Beberapa Segi Perkembangan Sejarah Pers di Indonesia 1979-1980. Jakarta: Kompas.

Takashi Shiraishi. "An Age in Motion: Popular Radicalism in Java, 19121926". Penerjemah. Hilmar Farid. 1997. Zaman Bergerak: Radikalisme Rakyat di Jawa, 1912-1926. Jakarta: Pustaka Utama Grafiti.

Taufik. I. 1977. Sejarah dan Perkembangan Pers Indonesia. Jakarta: Trinity Press.

Teguh Wahyu. 2011. Sejarah Nasional Asal Usul Bangsa dan Tanah Air. Yogyakarta: Pustaka Pelajar.

W. Poespoprodjo. 1986. Jejak-Jejak Sejarah 1908-1926: Terbentuknya Suatu Pola. Bandung: Penerbit Remaja Karya. 